\title{
Az Európa Tanács monitoringmechanizmusai és azok aktuális kihívásai
}

\section{Dr. Kocsis Gergö}

https://doi.org/10.47707/Kulugvi_Szemle.2021.2.03

Összefoglalás: A tanulmány áttekintést kíván adni az Európa Tanács monitoringmechanizmusainak rendszeréröl, amely az 1990-es években. a vasfüggöny leomlását követöen a szervezet jelentös tagállami bövité sének következtében jött létre. Bemutatásra kerülnek az Európa Tanács statútum szerinti szervei, azaz a Miniszteri Bizottság és a Parlamenti Közgyülés által létrehozott monitoringmechanizmusok, valamint az egyezményalapú és intézményi mechanizmusok. Az ellenörzö mechaniz musok áttekintését követöen pedig a rendszert érintö legjelentösebb. intézményen belüli és azon kivüli kihivásokat ismerteti a tanulmány.

Kulcsszavak: monitoring mechanizmus, Miniszteri Bizottság. Parlamenti Közgyülés

Abstract: The study aims to give an overview of the system of Council of Europe monitoring mechanisms, which were created in the 1990s as a consequence of the significant enlargement in the number of members states of the fall of the iron curtain. The study gives an introduction to the monitoring mechanisms created by the two statutory organs that is the Committee of Ministers and the Parliamentary Assembly, as well as an overview of the convention based and institutional monitoring mechanisms. Following the overview the takes stock of the most significant internal and external challenges faced by the mechanisms.

Keywords: monitoring mechanism. Committee of Ministers, Parliamentary Assembly 


\section{Bevezetés}

Az Európa Tanács 1949-es megalkotásától a rendszerváltozásig betöltött funkciója a tagállami kör 1990-es években bekövetkezett jelentős bővülésével alapjaiban változott meg. A II. világháborút követően kialakult hidegháborús világrendben a szervezet a nyugat-európai demokratikus államok közösségeként múködött. azonban ez a status quo megváltozott, amikor 1990. november 6-án Magyarország a korábbi keleti blokkból elsőként csatlakozott a szervezethez. A magyar belépést követően 1996-ig, az Orosz Föderáció csatlakozásáig mindössze pár év alatt 15 új tagállammal bő vült a szervezet a közép-kelet-európai térségből (ET-honlap, 47 Member States). Ez a radikális változás nemcsak új megközelítést kívánt meg a szervezet részérôl, hanem teljesen új munkamódszereket is. Mindezzel párhuzamosan a szervezetnek abban az európai intézményi munkamegosztásban is definiálnia kellett magát, amelyben az 1992-es maastrichti szerződést követően politikai unióvá formálódott Európai Közösségek, dinamizálódó bővítési folyamata meghatározó szerepet játszott.

Ajelen publikáció nem tér ki a fent említett bővítési folyamatra, va lamint az ahhoz vezető szervezeten belüli dilemmára. A tanulmány fókuszában a kialakított új ellenőrző, monitoringmechanizmusok állnak, amelyek ennek a folyamatnak a politikai következményeiként jöttek létre. Az 1990-1993 közötti radikális - 9 tagállammal való - bővítés folyamatában fontos momentum volt az első, 1993-as bécsi állam- és kormányfői csúcstalálkozó és annak zárónyilatkozata (Vienna Declaration), amely alapvető követelményeket fogalmazott meg a további tagfelvételre vonatkozóan. Ennek nyomán alakultak ki a szervezet tagsági követelményeit ellenőrző, statútum szerinti szervei által végzett monitoringtevékenységek, amelyeket a későbbiekben részletesebben bemutatok. Valamint létrejöttek az egyes szakterületeket lefedő egyezményekhez kötődő monitoringmechanizmusok, amelyek az adott nemzetközi kötelezettségvállalások végrehajtását hivatottak ellenőrizni. 


\section{Külïgyi Szemle}

Az ebből az igényből fakadó új nemzetközi eszközök létrehozása az elmúlt három évtizedben normává alakult, sőt a szervezet hár mas célkitűzésének - sztenderdalkotás, monitoring, kooperáció - egyik oszlopává vált.

A statútum szerinti szervek, valamint a szúkebb témájú egyezmények ellenőrzô mechanizmusai mellett az 1990-es években létrehozott új intézmények is kifejezetten rendelkeznek ellenőrző funkcióval. Így különösen az 1999-ben létrehozott emberi jogi biztos intézménye is egyfajta monitoringmechanizmus (CM Resolution (99)50), amelynek tevékenysége országspecifikus és tematikus emberi jogi vizsgálatokat is magában foglal.

A jelen írás célja a létrehozott monitoring rendszer összetettségének bemutatása, annak vizsgálata, hogy az 1990 óta eltelt három évtizedben organikusan fejlődő rendszer jelen formájában megfelel-e a jelenkor elvárásainak, továbbá melyek a legnagyobb kihívások, amellyel a monitoringmechanizmusok szembenéznek.

\section{Az Európa Tanács statútum szerinti szerveinek monitoringmechanizmusai}

\section{Miniszleri Bizoltság}

Az Európa Tanács három statútum szerinti szervvel rendelkezik: a Miniszteri Bizottsággal, a Parlamenti Közgyúléssel és a Főtitkárral, illetve az ôt segítő titkársággal. A Miniszteri Bizottság mint a szervezet fő döntéshozó testülete egy klasszikus kormányközi testület, mely a tagállamok kormányainak képviselőiből (külügyminiszterek és az őket helyettesítő nagykövetek) áll. A Miniszteri Bizottság a tagállami kötelezettségeknek való megfelelésrôl szóló 1994-es nyilatkozat (Declaration on compliance with commitments by member states) alapján hozott létre különböző monitoringeljárásokat. Ennek két fő formája az országspecifikus monitoring, valamint a tematikus monitoring. Országspecifikus 
monitoringra ezidáig 10 tagállam kapcsán került sor, amelyből 6 még mindig folyamatban van (Azerbajdzsán, Örményország, Bosznia és Hercegovina, Moldova, Szerbia és Montenegró). Azerbajdzsán, Örményország és Bosznia és Hercegovina esetében a monitoring a csatlakozás feltétele volt és minden esetben a csatlakozáskor a Parlamenti Közgyúlés által elfogadott ajánlásokon alapul.

AMiniszteri Bizottságországspecifikus monitoringtevékenysége elsősorban az adott állammal való együttmúködésre helyezi a hangsúlyt. A tevékenységet minden esetben országspecifikus akcióterv elfogadása és végrehajtása segíti. Ugyanakkor a folyamat a konszenzuskultúra miatt rendkívül lassú. Ezt jól mutatja például, hogy Azerbajdzsán esetében a 2017-2019 közötti időszakra vonatkozó monitoringjelentés tervezetét 2019. október 1-jei dátummal jegyezte az ET Politikai Ügyek Igazgatósága, azonban a jelentést csak mintegy másfél év elteltével, 2021. március 17-én fogadta el a Miniszteri Bizottság (CM/Del/Dec(2021)1399/2.3).

Továbbá jelentősen kritizálható a kiszámíthatatlansága az egyértelmű eljárási szabályok hiányossága miatt. Míg a többi, korábban monitoring alatt álló tagállam esetében inkább technikaiadminisztratív jellegű lezárásra került sor, egyedül Horvátország esetében született kifejezetten, expressis verbis Miniszteri Bizottsági döntés, hogy a monitoringeljárás lezárásra kerüljön.

A Miniszteri Bizottság másik - az országspecifikus monitoringhoz hasonlóan kalandos sorsú - tevékenysége a tematikus monitor ing. Ez a tevékenység is az 1994-es nyilatkozatot követően kezdődött meg, 1996 és 2007 között 12 témában került erre sor. Ugyan 2004-ben még új eljárási szabályokat fogadtak el, melyek alapján 2005-ben még lefolytatták a tematikus monitoringot, a tevékenységet 2005-ben már felfüggesztették. A Miniszteri Bizottság 2007-ben kidolgozott és elfogadott új szabálya (CM/ Del/Dec(2007)999/2.2) már csak ad hoc jelleggel teszi lehetővé a tematikus monitoringtevékenységet, azonban azóta ezt az eljárást nem alkalmazták. 


\section{Külïgyi Szemle}

\section{Parlamenti Közgyülés}

A szervezet bővítésére reagálva a Miniszteri Bizottsággal párhuzamosan a Parlamenti Közgyúlés is kidolgozta saját monitoring mechanizmusait, melyek a tagállamok által a csatlakozáskor vállalt kötelezettségek betartását vizsgálják. A Parlamenti Közgyúlés a témában 1993-tól kezdődően több határozatot is elfogadott, végül az 1997-es közgyúlési határozattal (PACE Resolution 1115(1997)) létrehozta a Monitoring Bizottságot mint a Parlamenti Közgyúlés egyik állandó bizottságát. Egyúttal létrejött a parlamenti monitoringeljárás ma is ismert rendszere is, amelynek lefolytatásáért a Monitoring Bizottság a felelős.

A Parlamenti Közgyúlés négy különböző monitoringeljárást hozott létre. A teljes monitoringeljárás (full monitoring procedure) egy tagállam csatlakozásakor kezdődik, és részét képezi, hogy két társraportőr rendszeresen látogatásokat tesz az érintett tagállamban. Jelenleg 11 tagállam áll teljes monitoring eljárás alatt Az eljárás alatt álló tagállamok közül kiemelendő Lengyelország, amely 1991-es csatlakozását követően nem állt monitoring eljárás alatt (ekkor még nem is létezett az eljárás), és a Parlamenti Közgyúlés 2020-ban helyezte teljes monitoring eljárás alá (PACE Resolution 2316 (2020)). Szintén különleges esetnek minősüil Törökország, amely 1950. április 13. óta a szervezet tagja, így 1996-ban nem a kilencvenes években csatlakozott új tagállamként került monitoring eljárás alá. Törökország 1996 2004 között állt teljes monitoring alatt, majd 2004-től 2017-ig posztmonitoring-eljárás alatt, azonban a törökországi politikai fejlemények miatt 2017 óta ismét teljes monitoring eljárás alatt áll (PACE Resolution 2156 (2017)).

Azon államok esetében, ahol a Parlamenti Közgyúlés azt állapítja meg, hogy a csatlakozáskor vállalt kötelezettségeknek való megfelelésben, valamint az Európa Tanács sztenderdjeinek alkalmazásában

1 Albánia, Örményország, Azerbajdzsán, Bosznia és Hercegovina, Georgia, Moldova, Lengyelország, Oroszország, Szerbia, Törökország és Ukrajna. 
előrelépés történt, lezárásra kerül a teljes monitoringeljárás és egy kevésbe intenzív, úgynevezett posztmonitoring párbeszédre kerül sor, amely tartalmát tekintve is szűkebb fókuszú. Jelenleg három tagállam Bulgária, Észak-Macedónia és Montenegró áll posztmonitoring párbeszéd alatt. Bulgária 1994-2000 között, Montenegró 2007-2015 között, Észak-Macedónia 1996-2000 között volt teljes monitoring alatt, azóta posztmonitoring párbeszéd alatt állnak. Az elhúzódó folyamat folyamatos kritikának van kitéve, különösen a 21 éve posztmonitoring alatt álló EU-tagállam Bulgária által.

A két strukturáltabb monitoring mechanizmus mellett 2014-től bevezetésre került a tagállamok időszakos felülvizsgálata (PACE Resolution 2018 (2014)), amely azon államok vonatkozásában vizsgálja a tagságból fakadó kötelezettségek betartását, amelyek nem állnak teljes monitoringeljárás vagy posztmonitoring párbeszéd alatt. 2015 óta 16 időszakos felülvizsgálati jelentés készült el (AS/ Mon/Inf (2019) 02), és jelenleg három: Magyarország, Málta és Románia áll előkészítés alatt. Az új mechanizmus indulását követô elsô 16 jelentés az angol betűrend sorrendjét követte Andorrától Olaszországig vizsgálta a tagállamokat, azonban 2019-ben a Monitoring Bizottság elnökének javaslatára megváltoztatták a felülvizsgálandó államok kiválasztásának módszertanát. A változással kapcsolatban 2019. május 16-án a Parlamenti Közgyűlés Bürója az eljárási kérdésekért felelős bizottsághoz fordult. Azt követően, hogy az Eljárási, Mentelmi és Intézményi Ügyekért felelős Bizottság a Parlamenti Közgyúlés szabályaival összeegyeztethetőnek tartotta az új módszertant, 2020. január 16-án elindult a három érintett tagállam (Magyarország, Málta, Románia) időszakos felülvizsgálata. Az új szempontrendszert a Monitoring Bizottság a belső munkamódszereiben rögzítette (PACE Resolution 2357 (2021)). Az idôszakos felülvizsgálat alá vonáshoz egy hármas szubsztantív szempontrendszer került meghatározásra: az Európa Tanács monitoring [egyezményalapú vagy intézményi] testületeinek megállapításai; a Parlamenti Közgyúlés más bizottságai által készített 


\section{Külïgyi Szemle}

jelentések megállapításai; valamint a bizottság tagjai, nemzetközi és nemzeti civil szervezetek és a média által felvetett kérdések egy tagállam demokratikus intézményeinek múködését illetően. Magyarország az első tagállam, amely másodszorra tárgya az időszakos felülvizsgálatnak, miután 2018-ban az angol betűrend sze rinti sorrendben került rá sor, majd a megváltozott munkamódszer alapján is jelentés készül Magyarországról.

Végezetül a Parlamenti Közgyúlés Monitoring Bizottság 2013-ban létrehozott mechanizmusa (PACE Resolution 1936 (2013)) a jelentéskészítés a demokratikus intézmények mûködéséről egy tagállamban, ha egyes fejlemények ezt szükségeltetik. Az eljárás létrehozására azért került sor, hogy strukturáltabb módja legyen annak, ha a Parlamenti Közgyúlés tagjai kezdeményezik egy tagállammal kapesolatban a monitoringeljárás alá helyezést, ahogyan tették ezt Magyarország esetében (PACE Resolution 1941(2013)). Demokratikus intézmények működéséről szóló jelentés ezidáig csak Lengyelország vonatkozásában készült (PACE Resolution 2316 (2020)), amelynek eredményeként 2020 januárjában Lengyelország teljes monitoringeljárás alá helyeződött.

A két statútum szerinti szerv, azaz a Miniszteri Bizottság és a Parlamenti Közgyúlés mechanizmusait összehasonlítva egyértelműen látható, hogy a hatékonyabb és strukturáltabb tevékenységgel ezen a területen a parlamenti dimenzió rendelkezik, azonban ez sem mentes a kihívásoktól és a kritikáktól. A Parlamenti Közgyűlés monitoringreformját sürgető tagállamok érvrendszerében megjelenik, hogy a csatlakozásuk óta monitoring alatt álló tagállamok esetében nem teljesen egyértelmú, hogy milyen feltételeknek kell megfelelniük az eljárás lezárásához, nem léteznek világosan meghatározott mérföldkövek, amelyeket teljesíthetnének. A csatlakozásuk óta eltelt jelentős idővel természetesen az a kérdés is felmerül, hogy a követelményrendszer folyamatosan adaptálódik-e a megváltozott politikai-történelmi kontextushoz. Hasonlóan érvelnek a posztmonitoring párbeszéd alatt álló tagállamok, különösen a 21 év óta ugyanazon eljárás alatt álló Bulgária, amely 2007 óta 
az Európai Unió tagja. Az időszakos felülvizsgálati eljárás 2015-től 2019-ig alkalmazott módszertanát, abból a szempontból érte kri tika, hogy nem képes a gyors reakciókra és nem elég rugalmas azáltal, hogy az angol betűrendet követi. Erre az igényre válaszul született meg a Monitoring Bizottság új belsô munkarendje, amely azonban olyan új szubjektív szempontokat vezet be a döntéshozatali folyamatba, mint a nemzetközi és nemzeti civil szervezetek és a média által felvetett kérdések, amelyek biztosan előrevetítik az eljárás politikai kritikáit.

\section{Egyezményalapú és intézményi mechanizmusok}

Az Európa Tanács az elmúlt három évtizedben kidolgozta a különböző szakterületekhez füződő monitoring mechanizmusokat is, amelyek alapjai az Európa Tanács égisze alatt megszületett nemzetközi egyezmények vagy a Miniszteri Bizottság határozatai. Ezeket a mechanizmusokat többféleképpen csoportosíthatjuk, így például az alapján, hogy országspecifikus vagy tematikus monitoring tevékenységet végez, hogy milyen összetételű a monitoringot végző testület és nem utolsó sorban szakterület szerint. A következőkben a mechanizmusok tematikus bontásban a fenti szempontok szerint kerülnek bemutatásra.

Az Európa Tanács három diszkrimináció-ellenes monitoring mechanizmussal rendelkezik, ide sorolható a Nemzeti Kisebbségek védelméről szóló Keretegyezmény (FCNM) és a Regionális vagy Kisebbségi Nyelvek Európai Chartája (ECRML) végrehajtásának ellenőrzése, valamint a Rasszizmus és Intolerancia Elleni Európai Bizottság (ECRI) tevékenysége. Mindhárom diszkrimináció-ellenes monitoring mechanizmus az 1993-as bécsi állam-és kormányfői csúcstalálkozó eredményeként jött létre a kilencvenes években. Míg a Kisebbségvédelmi Keretegyezmény és a Nyelvi Charta egyezményalapú monitoringmechanizmusok, addig az ECRI statútumát a Miniszteri Bizottság egy 2002-es határozata hozta létre 


\section{Külïgyi Szemle}

(CM Resolution 2002(8)). A két kisebbségvédelmi egyezmény vég rehajtásának ellenőrzését egy-egy szakértőkből álló testület segí ti (ECRML-COMEX, FCNM AC), azonban a tagállamok felé tett ajánlásokat a Miniszteri Bizottság határozat és ajánlás formájában fogadja el. Az a tény, hogy mindkét kisebbségvédelmi egyez mény végrehajtásának ellenőrzésében jelentős szerepet kapott a kormányképviselőkből álló Miniszteri Bizottság, megkülönbözteti ezeket a mechanizmusokat az összes többi monitoring tevékeny ségtől, amely minden bizonnyal a téma érzékenységének köszön hető. Szakértői testületeik tagjait szintén a Miniszteri Bizott ság választja a részes államok jelölései alapján. Ezzel szemben az ECRI monitoringtevékenységében a Miniszteri Bizottságnak nincs tényleges szerepe, a testület függetlenül jár el, habár tagjait a tagállamok nem választják, hanem kijelölik. Az ECRI tagjainak száma megegyezik a tagállamok számával. Mindhárom testület közös vonása, hogy 5 éves monitoringciklusokkal országspecifikus jelentéseket készítenek. Az ötéves cikluson belül pedig utóköve tésre is sor kerül, ami az ECRI és a Nyelvi Charta esetében az eljárás része, míg a Kisebbségvédelmi Keretegyezménynél csak ajánlott. Mindhárom mechanizmus országspecifikus munkát végez, és az országlátogatás tevékenységüik fontos részét képezi. A két kisebbségvédelmi mechanizmusra vonatkozóan 20 évvel hatályba lépésüket követỏen, 2018-ban került sor egy-egy reformra, hogy eljárásaik a két évtized tapasztalatai alapján legyenek kiigazítva.

Az ET égisze alatt több büntetőjogi tárgyú monitoring me chanizmus is létrejött. Ezek egyik csoportja a pénzüigyi kérdésekkel foglalkozó Moneyval és GRECO, míg másik csoportba a sérülékeny csoportokat védő büntetőjogi egyezményeken alapuló monitoringmechanizmusok sorolhatók, azaz GRETA, GREVIO, Lanzarote Bizottság. Az emberkereskedelem elleni egyezmény végrehajtásának ellenőrzéséért a Részes Államok Bizottsága a felelős, amelybe az egyezmény részes államainak kormányzati képviselői vesznek részt, azonban a munkáját segíti egy 15 fős választott szakértői testület a GRETA (Group of Experts on Action against Trafficking 
in Human Beings). Munkájukat egy-egy témát országspecifikusan feldolgozva végzik, országlátogatásra pedig csak ad hoc alapon, szükség szerint kerül sor. Eljárási szempontból szinte teljesen megegyezik a nőkkel szembeni erőszak és a kapcsolati erőszak elleni küzdelemről és azok megelőzésérôl szóló Isztambuli Egyezmény monitoringmechanizmusa az emberkereskedelem elleni mechanizmussal. Ugyanúgy két szerv felelős a végrehajtás ellenörzéséért, egy kormányképviselőkből álló és egy 15 fős szakértői testület (Group of Experts on Action against Violence against Women and Domestic Violence, GREVIO) és az ellenőrzés metódusa is egyezik. A gyermekek szexuális kizsákmányolás és szexuális zaklatás elleni védelméról szóló egyezménye az úgynevezett Lanzarote Egyezmény bár tartalmában rendkíviul hasonló, azaz büntetőjogi eszközökkel véd egy sérülékeny csoportot, azonban a monitoring mechanizmusa kevésbé kiforrott. Tematikus és nem országspecifikus munkát végez a Lanzarote Bizottság, amelynek tagjai a kormányok képviselői, és munkájukat nem segíti szakértői testület. A munkamódszer eredetileg egy kezelhető mére tủ tagállami körre lett kitalálva, azonban időközben a Lanzarote Egyezményt az Európa Tanács minden tagállama és Tunézia is ratifikálta (Treaty Office website), így már 48 államban kellene ellenôrizni a végrehajtást, amelyre a jelen struktúra már nem alkalmas. Ennek megfelelően megindult egy reform gon dolkodás, hogy akár a GRETA és a GREVIO mintájára alakul jon át a monitoringtevékenység (List of decisions of Lanzarote Committee, T-ES(2019)09).

Szintén büntetőjogi együttműködés részeként jött létre 1999 ben a Korrupció Elleni Államok Csoportja (Group of States against Corruption - GRECO), amely nem kizárólag egy egyezmény, ha nem több releváns sztenderd végrehajtását is ellenôrzi országonként, tematikus monitoringkörökben. A GRECO maga egy kibő vített részegyezményként működik, tehát az ET-n kívüli államok is csatlakozhatnak hozzá, így 50 tagja között ott van az Egyesült Államok, Belarusz és Kazahsztán is. A monitoringszervvel kapcsolatban 


\section{Külïgyi Szemle}

kiemelendô továbbá, hogy a területen szorosan együttmúködik más nemzetközi szereplőkkel, így az OECD, UNODC, OAS vonat kozó mechanizmusaival. A GRECO-hoz hasonlóan a Pénzmosás és Terrorizmus Finanszírozása Elleni Intézkedéseket Értékelő Szakértỏi Bizottság (MONEYVAL) nem egy egyezmény végrehajtásának ellenőrzésére jött létre, hanem a pénzmosás és a terrorizmus finanszírozása elleni nemzetközi sztenderdek átültetését vizsgálja. A Moneyval elődje (PC-R-EV) 1997-ben jött létre, majd Moneyval néven 2010 óta független monitoring szervként múkö dik a Miniszteri Bizottság alatt. A Moneyval az ET mechanizmu sai között azért is kivételes, mert a pénzmosás és terrorizmus finanszírozása elleni küzdelem nemzetközi sztenderdjeit meghatározó globális szintű kormányközi szervezet, a Pénzügyi Akciócsoport (Financial Action Task Force, FATF) regionális európai monitoring szerve.

Az Európa Tanács Kínzás és embertelen vagy megalázó bün tetések vagy bánásmód megelőzésére alakult Európai Bizottsága (CPT) a kínzás és az embertelen vagy megalázó büntetések vagy bánásmód megelôzésérôl szóló egyezmény végrehajtásának ellenőrzéséért felel. A CPT egyike azon mechanizmusoknak, amelynek mind a 47 ET-tagállam részese. A bizottság különleges munkamódszerekkel dolgozik, így pl. delegációi korlátozás nélkül kereshetnek fel fogvatartási intézményeket, és az egyes intézményeken belül is szabadon mozoghatnak, valamint négyszemközti beszélgetéseket folytathatnak a szabadságuktól megfosztott személyekkel. Munkamódszerük fontos része a bizalmasság, amelyet a tevekénységüik alapjául szolgáló egyez mény is alapelvként kezel, így jelentéseiket csak az érintett államok beleegyezésével hozhatják nyilvánosságra. Ez egyben az ET legrégebbi monitoring mechanizmusa, amely 1990 óta múködik. A GRECO-hoz és a Moneyvalhoz hasonlóan a CPT szo rosan kapcsolódik más globális mechanizmusokhoz, így folya matosan együttmúködik a duplikációk elkerülése érdekében a kínzás és más kegyetlen, embertelen vagy megalázó büntetések 
vagy bánásmódok elleni ENSZ-egyezmény kiegészítő jegyzőkönyvének (OPCAT) végrehajtását ellenőrző független szakértőkből álló Megelőzési Albizottsággal.

Szociális jogok terén szintén kiterjedt tevékenységet végez az Európa Tanács, amely az 1961-ben elfogadott Szociális Jogok Európai Chartájának evolúciója miatt több rétegből tevődik össze. Egyrészt az 1961-es Charta 22. cikke is meghatároz egyfajta laza jelentéstételi kötelezettséget a tagállamoknak az egyezmény el nem fogadott rendelkezéseit illetően. Ezen felül évente tematikus jelentést készítenek a tagállamok a Charta végrehajtásáról, amelyet a tagállamok által választott 15 tagú Szociális Jogok Európai Bizottsága (SZJEB) értékel. A szociális jogok terén a legmagasabb szintű monitoringtevékenységet a kollektív panaszmechanizmus biztosítja, amelyet eddig mindössze 15 tagállam ratifikált. A kollektív panaszmechanizmus keretében ér dekvédelmi szervezetek fordulhatnak közvetlenül a Szociális Jogok Európai Bizottságához, amelynek az egyedi ügyekben meghozott döntései egyes tagállamokban az Emberi Jogok Európai Bíróságának döntéseihez hasonlóan közvetlen hatállyal bírnak. Tekintettel arra, hogy a több párhuzamos eljárás miatt a monitoringtevékenység hatékonysága javításra szorul, az ET főtitkárának kezdeményezésére 2021 február jában megalakult egy magas szintű csoport, amely konkrét javaslatokat tesz a szociális jogok védelmének javítása érdekében² ${ }^{2}$

A fenti emberi jogi monitoring mechanizmusokon túl említést érdemel, hogy az Európa Tanácsnak három sportegyezményéhez, a mesterséges teljesítményfokozó szerek használata elleni egyez ményhez (Antidopping Egyezmény), a sportesemények biztonságáról szóló egyezményhez (Saint Denis-i Egyezmény) és a sportversenyek jogellenes befolyásolása elleni egyezményhez (Macolin Egyezmény) is kötődik monitoringmechanizmusa.

Szintén elküiönüil jellegében az emberi jogi monitoring mechaniz musoktól, azonban említést érdemel az 1994-ben az ET tanácsadó szerveként létrejött Európai Helyi és Regionális Önkormányzatok

2 https://www.coe.int/en/web/european-social-charter/-/lst-meeting-of-the-highlevel-group-of-experts-on-social-rights 


\section{Külïgyi Szemle}

Kongresszusa, amely amellett, hogy a helyi politikai szint páneurópai fóruma, monitoringszervként is feladatot lát el a Helyi Önkormányzatok Európai Chartája végrehajtásának ellenőrzésével. E feladatában eljárva a tagállamokat meghatározott 5-6 éves ciklusonként vizsgálják, és tagállamonként jelentést fogadnak el a helyi és regionális önkormányzati politikusok.

\section{Intézményen belïli kihívások}

A monitoring kapcsán a legfontosabb intézményen belüli kihívások a tagállamok együttmúködési készsége a különböző mechanizmusokkal, az egyezmény- és határozatalapú mechanizmusok szervezési és eljárási kérdései, a tematikus átfedések és a statútum szerinti szervek közötti együttmúködés hiányosságai.

A monitoringmechanizmusok több szempontból is hatékonysági kihívásokkal küzdenek. Ennek egyik legfőbb jele az úgynevezett "monitoring fatigue” azaz monitoring fáradtság, ami annyit tesz, hogy a tagállamoknak a mechanizmusokban való aktív részvétele jelentős mértékben visszaesett. Ez a jelenség nagyon jól megfigyelhető a két kisebbségvédelmi monitoringmechanizmus esetében, így különösen a Regionális vagy Kisebbségi Nyelvek Európai Chartáját illetően, ahol a hároméves monitoringciklusokat figyelmen kívül hagyva volt olyan részes állam, amely hat év után nyújtotta csak be az ellenőrzési folyamat elindításához szükséges országjelentést. Ez a jelenség volt az egyik oka annak, hogy 2018. november 28-án elfogadásra került az a Miniszteri Bizottsági határozat $(\mathrm{CM} / \mathrm{Del}$ Dec(2018)1330/10.4e), amely megreformálta a mechanizmust, átalakítva annak jelentési időszakait.

Hasonlóképp a monitoringfáradtság jele lehet, hogy az ETszervek által tett ajánlások végrehajtása számos esetben kimutathatóan romló tendenciát mutat. Ennek talán legjellegzetesebb példája a GRECO-ajánlások végre nem hajtása. Az ajánlások 
elégtelen végrehajtása miatt a GRECO 2019-es éves általános jelentése szerint 15 tagállam állt meg nem felelóségi eljárás alatt (non-compliance procedure, 20th General Activity Report).

A hatékony működést kérdőjelezi meg továbbá az egyes monitoringmechanizmusok közötti tematikus átfedés. Ennek egyik példája a Nemzeti Kisebbségek védelméről szóló Keretegyezmény és az ECRI-bizottság jelentései közötti átfedés az antiszemitizmus terén, mivel a Keretegyezmény szakértői az általános anti-diszkriminációs klauzulán keresztül (Kisebbségvédelmi Keretegyezmény, 6. cikk) foglalkoznak a kérdéskörrel (kivétel azok az államok, ahol a zsidóság nemzeti kisebbség, pl. Lengyelország), míg az ECRI mandátumából fakadóan vizsgálja a kérdéskört. Hasonlóan bonyolult a helyzet a migrációt illetően, amely egyetlen monitoringmechanizmusnak sem tárgya, részeivel azonban többen is foglalkoznak. E tárgykörben külön kiemelendő a magyar-szerb határszakasz, amellyel kapcsolat ban ad hoc monitoringtevékenységet végzett a GRETA (GRETA(2018)13), a CPT (CPT/Inf(2018)42) és a Lanzarote Bizottság (T-ES(2017)11), valamint az ET-fôtitkár migrációs ügyekért felelős különleges képviselője (SG/Inf(2017)33). A jelentések évszámából látható az időbeli összetorlódás, emellett pedig a téma duplikációja, az egyeztetés hiánya és az eltérő jogi módszertani alapok végüil egy kaotikus összképet eredményeztek, amely nem tette lehetővé az ET-sztenderdeknek való megfelelés egyértelmủ, hatékony vizsgálatát.

Az eljárási és szervezési kérdések mellett fontosak az ET statútum szerinti szervei közötti kommunikációs, egyeztetési kihívások is. A Miniszteri Bizottság monitoringmechanizmusa és a Parlamenti Közgyúlés monitoringtevékenysége, bár valójában egymásra épüil, „külön életet él”, és az ezek keretében ho zott döntéseknek nincs eljárási következményük egymásra vonatkozóan. Így a Parlamenti Közgyúlés monitoringvizsgálata nem eredményezi automatikusan azt, hogy a Miniszteri Bizottság is monitoringtevékenységet folytat egy tagállammal kapcsolatban 


\section{Külïgyi Szemle}

(lásd Lengyelország). A vizsgált államok eltérô köre még nyilvánva lóbb az egyezmény- és határozatalapú monitoringmechanizmusok tekintetében, ahol a vizsgált államok köre jelentősen eltér attól füiggően, hogy mely állam ratifikálta a monitoringtevékenység alapját jelentő egyezményt. Vannak olyan mechanizmusok, amelyben minden tagállam részt vesz és van, amelynek résztvevői köre meglehetősen korlátozott, így például az anti-diszkriminációs területen az ECRI-monitoringnak alanya mind a 47 tagállam, míg a Regionális vagy Kisebbségi Nyelvek Európai Chartáját mindöszsze 25 tagállam ratifikálta. Ugyanakkor kijelenthető, hogy a Parlamenti Közgyúlés jelentős mértékben épít az egyes egyezményvagy határozatalapú monitoringmechanizmusok megállapításaira.

A hatékonyság javítása folyamatosan a szervezet napirendjén van. A kérdéskör egyes mechanizmusokkal kapcsolatban is felmerül, mint a két kisebbségvédelmi egyezmény esetében, ahol mindez egy-egy monitoringmechanizmust reformáló Miniszteri Bizottsági határozat elfogadásához vezetett $(\mathrm{CM} /$ Del/Dec(2018)1330/10.4e és Resolution CM/Res(2019)49), de a Lanzarote Bizottságban szintén megindult a hatékonyságot célzó reformról való gondolkodás. Van olyan eset is, ahol egészen apró változtatással igyekeznek fellendíteni a szakmai munkát, pl. a GRETA Részes Államok Bizottsága a 2019. október 18-ai ülésén úgy döntött, hogy a munkájába a jövőben nagyobb mértékben kapcsolja be a fơvárosi szakértőket (Meeting Report, THB-CP(2019) RAP25). A Parlamenti Közgyúlés maga is több ízben reformálta a 1997-ben elindított monitoringmechanizmusát, bevezetve az idôszakos felülvizsgálati eljárást, amely minden tagállamot érint (PACE Resolution 2018 (2014)), és 2020-ban pedig a PKGY Monitoring Bizottsága elfogadta erre vonatkozóan a legújabb munkamódszereit (PACE Resolution 2357 (2021)). Az egyes mechanizmusokat érintő munkán túl rendszeresen felmerül a teljes rendszer felülvizsgálatának igénye, amely a Miniszteri Bizottság 129. külügyminiszteri szintű ülésén (Helsinki, 2019. május 16-17.) is megfogalmazásra került (CM/Del/Dec(2019)129/2). Hasonló célkitűzést 
fogalmazott meg az ET Fótitkára is a Stratégiai Keret dokumentumában (SG/Inf(2020)34), amelynek következtében felállítás ra került az Monitoringgal kapcsolatos Ad Hoc Munkacsoport (GT-MON), amelynek mandátuma szerint 2021. április 30-ig kell jelentést készítenie a monitoringmechanizmusok esetleges reformjával kapcsolatban (CM/Del/Dec(2021)1393/1.7).

Végezetül e belső intézményi kihívások tárgyalása során meg kell említeni az úgynevezett közös reakciós mechanizmust, amely nem klasszikus értelemben vett monitoringmechanizmus, azonban az ET Statútum megsértésének legsúlyosabb eseteiben megteremti annak lehetőségét, hogy a szervezet statútum szerinti szervei (Miniszteri Bizottság, Parlamenti Közgyúlés, Fótit kár) közösen lépjenek fel egy tagállam vonatkozásában, és olyan vizsgálati tevékenységet folytassanak, amelynek célja a statútumnak megfelelő állapot helyreállítása. Az új eljárás megalkotására szintén a helsinki külügyminiszteri ülés döntése alapján került sor, és célja volt többek között annak a helyzetnek a feloldása, hogy a Parlamenti Közgyúlés a Krím-félsziget és Szevasztopol illegális annektálását követően az Oroszországgal szemben elfogadott szankciói során megvonta az orosz PKGY-delegáció szavazati jogát (PACE Resolution 1990 (2014)), amelyet egyoldalúan, a Miniszteri Bizottság nélküil nem tehetett volna meg. Az új eljárás (amely múltbeli kérdések kezelésére elvileg nem alkalmas) el fogadása óta még egyetlen tagállammal szemben sem indult meg.

\section{Intézményen kíviili kihívások}

Az intézményen belüili problémák mellett jelentős küilső kihívást jelent az ET monitoringmechanizmusok számára az 1990-es évek óta megváltozott külpolitikai környezet, és az elmúlt három évtizedben az Európai Unió átalakulása, szerepének fejlődése. Mint láthattuk, a monitoringmechanizmusok létrejötte szoros összefüggésben áll a vasfüggöny lebomlásával és a közép-kelet-európai 


\section{Külïgyi Szemle}

államok euroatlanti integrációs törekvéseivel, tulajdonképpen annak a folyamatnak az egyik következménye. A külpolitikai környezetben azonban jelentős változás következett be az elmúlt három évtizedben azáltal, hogy az 1990 után csatlakozott ET-tagállamok jelentős része is az Európai Unió tagállamává vált, ennek következtében pedig az a fontos szerep, amelyet az ET sztenderdjeinek átuiltetése játszott ebben az integrációs folyamatban, elvesztette jelentőségét. Az ET-monitoring bár továbbra is rendkívül fontos támpontot nyújt az EU-tagjelöltek csatlakozási tárgyalásai során, abból fakadóan, hogy a közeljövőben nincs realitása egyetlen állam csatlakozásának sem az EU-hoz, a kifejtett hatás sokkal kisebb jelentőségű, mint a mechanizmusok létrehozásának idején.

Az Európai Unió bővítése mellett legalább ekkora vagy még nagyobb hatású folyamat az ET szempontjából az EU politikai dimenziójának mélyülése. Az EU mint politikai unió a maastrichti szerződés következtében jött létre 1993-ban, és azóta egy folyamatosan mélyülő együttműködésről beszélhetünk, amely fokozatosan egyre inkább kiterjedt azokra a területekre is, amelyekért a nemzetközi intézmények európai architektúrájában hagyományosan az Európa Tanács volt a felelős. 2000-ben megalkotásra került az EU Alapjogi Chartája, 2007-ben létrehozták az EU Alapjogi Ügynökségét, és a lisszaboni szerződés hatályba lépése óta a luxembourgi Európai Unió Bírósága megfelelő jogalap pal rendelkezik ahhoz, hogy olyan ügyekben hozzon ítéletet, amelyek korábban egyértelműen a strasbourgi Emberi Jogok Európai Bírósága ítélkezésében jelentek volna csak meg. Ugyan a lisszaboni szerződés kötelezi az EU-t az Emberi Jogok Európai Egyezményéhez való csatlakozásra, erre a mai napig nem került sor. Az EU ugyanakkor 2014-ben megalkotta az EUSz. 7-es cikk gyakorlati alkalmazhatóságát lehetővé tevő, a jogállamiság megerősítésére irányuló új uniós keretet, valamint legújabban a 2019. júliusi döntést követően az Európai Bizottság 2020-tól kezdve éves jogállamisági jelentést készít a tagállamairól. Mindebből az tűnik ki, hogy az EU tagállamainak vonatkozásában egy saját monitoring 
mechanizmust hozott létre. Figyelemreméltó ugyanakkor, hogy az EU éves jogállamisági jelentésének egyik legfőbb forrása maga az ET és annak monitoringmechanizmusai. A 2020-ban publikált jogállamisági jelentés témáival kapcsolatban minden EU-tagállam vonatkozásában küldött az ET felhasználható anyagot az Európai Bizottságnak (stakeholder contribution). Így csak a magyar országfejezet 26 alkalommal hivatkozik a GRECO-ra, 24 alkalommal a Velencei Bizottságra és 34 alkalommal az Európa Tanácsra.

A fontos külső kihívások számbavételekor felmerül tehát a kérdés, hogy annak a 27 ET-tagállamnak, amely egyben EU-tagállam is, mely mechanizmusokat érdemes követnie, milyen sztenderdeknek kell megfelelnie, és egyáltalán érdekében áll-e két egyformán erősen működő kontrollmechanizmus fenntartása. Ha az EU-tagállamok vonatkozásában az ET veszít a jelentőségéből, akkor valójában az is fontos kihívás, hogy miként lehet vonzó az ET és annak mechanizmusai a nem EU-tagállam ET-tagállamoknak. Milyen együttműködés képzelhető el az EU-n kívüli nagy tagállamokkal, az Egyesült Királysággal, Oroszországgal és Törökországgal? Mi a jelentősége a távlati EU-csatlakozási perspektívákkal rendelkező nyugat-balkáni államok szempontjából? Vagy a posztszovjet térség konfliktusokkal terhelt államai számára?

\section{Konklúzió}

Az Európa Tanács monitoringmechanizmusok rendszerének áttekintését követôen látható, hogy egy komplex, sokszereplős, fragmentált eszközrendszerről van szó, amellyel kapcsolatban valószínúleg a legnagyobb hiányosságként a rendszerszintűség hiánya róható fel. A szisztematikus gondolkodás hiányát mutatja nemcsak az, hogy a szereplők között tartalmi duplikációkra kerül sor, hanem a mechanizmusok eljárási szempontú összhangjának 


\section{Külïgyi Szemle}

hiánya is. Így nemcsak a statútum szerinti szervek tevékenységei között nincs közvetlen összefüggés, hanem az egyezményalapú és intézményi monitoringmechanizmusok közötti koordináció is csak informális. A monitoring rendszer összeségének szempontjából érthetetlen, hogy egymáshoz tematikusan közel álló egyezmények esetében is eltér az ellenőrzési mechanizmus módja, így például a büntetójogi területen a 2005. évi GRETA, a 2007. évi Lanzarote Bizottság és a 2011-es GREVIO esetében. Ígéretes folyamat, hogy a rendszer töredezettségéból fakadó kihívások orvoslására több kezdeményezés is indult az elmúlt években, mint a két kisebbségvédelmi egyezmény mechanizmusainak reformja, a Lanzarote Bizottság reformja vagy az ET-fótitkár 2021-es Stratégiai Kerete alapján. Ugyanakkor látható, hogy ezek ambíciószintje csak az egyezményalapú mechanizmusokra terjed ki.

Történelmi perspektívából a rendszerszintű múködés hiánya mellett is sikeresnek értékelhetók az Európa Tanács mechaniz musai, amennyiben küldetésüknek azt tekintjük, hogy hozzájárultak a vasfüiggöny lebontása után a közép-kelet-európai régió euroatlanti integrációjához, a demokratikus intézmények megteremtéséhez, az emberi jogi normák kialakításához. Ugyanakkor részben ebből a sikerből fakad az Európa Tanács legnagyobb küilső kihívása: az Európai Unióval való viszonyának meghatározása. A teljes szervezet és ebből fakadóan a monitoringmechanizmusok rendszerének szempontjából is a legfontosabb megválaszolandó kérdés, hogy az Európa Tanács miként tud reagálni arra a megváltozott politikai realitásra, mely szerint tagállamainak több mint fele az Európai Unió tagja, amely az elmúlt három évtizedben a politikai unió megteremtésének részeként jelentős erőforrásokat fordított arra, hogy kiépítse saját emberi jogi, demokrácia- és jogállamisági sztenderdjeit és mechanizmusait. 


\section{Irodalom}

Committee of Ministers Resolution (99) 50 on the Council of Europe Commissioner for Human Rights, 1999. május 7.

CM/Del/Dec(2021)1399/2.3, Decision of the Ministers' Deputies, Activities for the development and consolidation of democratic stability Azerbaijan, 2021. március 17.

CM/Del/Dec(2007)999/2.2, Decision of the Ministers'Deputies, Discussion on future arrangements for thematic monitoring, 2007. július 5.

Parliamentary Assembly Resolution 1115 (1997), Setting up of an Assembly committee on the honouring of obligations and commitments by member states of the Council of Europe (Monitoring Committee), 1997. január 29.

Parliamentary Assembly Resolution 2316 (2020), The functioning of democratic institutions in Poland, 2020. január 28.

Parliamentary Assembly Resolution 2156 (2017), The functioning of democratic institutions in Turkey, 2017. április 25.

AS/Mon/Inf(2019)02, Monitoring Committee: Work Overview, Committee on the Honouring of Obligations and Commitments by Member States of the Council of Europe (Monitoring Committee), 2021. február 15.

Parliamentary Assembly Resolution 2357 (2021), Progress of the Assembly's monitoring procedure (January-December 2020), 2021. január 25.

Parliamentary Assembly Resolution 1936 (2013), Harmonisation of regulatory and para-regulatory provisions of monitoring and post-mo nitoring dialogue procedures, 2013. május 31.

Parliamentary Assembly Resolution 1941 (2013), Request for the opening of a monitoring procedure in respect of Hungary, 2013. június 25.

Committee of Ministers Resolution 2002 (8) on the statute of the Europe an Commission against Racism and Intolerance, 2002. június 13.

20th General Activity Report (2019) of the Group of States against Corruption (GRECO), 2020. március 25. 


\section{Külïgyi Szemle}

GRETA(2018)13, Report on Hungary under Rule 7 of the Rules of Procedure for evaluating implementation of the Council of Europe Convention on Action against Trafficking in Human Beings, 2018. március 23.

CPT/Inf (2018) 42, Report to the Hungarian Government on the visit to Hungary carried out by the European Committee for the Prevention of Torture and Inhuman or Degrading Treatment or Punishment (CPT) from 20 to 26 October 2017, 2018. szeptember 18.

T-ES(2017)11, Special report further to a visit undertaken by a delegation of the Lanzarote Committee to transit zones at Serbian/Hungarian border (5-7 July 2017), 2018. január 30.

SG/Inf(2017)33, Report of the fact-finding mission by Ambassador Tomás Boček, Special Representative of the Secretary General on migration and refugees to Serbia and two transit zones in Hungary 12-16 June 2017, 2017. október 13.

CM/Del/Dec(2018)1330/10.4e, Decision of the Ministers' Deputies, Strengthening the monitoring mechanism of the European Charter for Regional or Minority Languages, 2018. november 28.

$\mathrm{CM} / \operatorname{Res}(2019) 49$, Committee of Ministers Resolution on the revised monitoring arrangements under Articles 24 to 26 of the Framework Convention for the Protection of National Minorities, 2019. december 11.

List of decisions of Lanzarote Committee, Committee of the Parties to the Council of Europe Convention on the protection of children against sexual exploitation and sexual abuse, T-ES(2019)09, 2019. március 7.

Meeting Report of 25th meeting of the Committee of the Parties of the Council of Europe Convention on action Against Trafficking in Human Beings, THB-CP(2019)RAP25, 2020. január 16.

Parliamentary Assembly Resolution 2018 (2014), The progress of the Assembly's monitoring procedure (October 2013-September 2014), 2014. október 2.

CM/Del/Dec(2019)129/2, Decision of the Committee of Ministers, A shared responsibility for democratic security in Europe, 2019. május 17. 
CM/Del/Dec(2021)1393/1.7, Decision of the Ministers' Deputies, Strategic Framework of the Council of Europe, 2021. január 20.

$\mathrm{CM} / \operatorname{Del} / \operatorname{Dec}(2020) 1366 / 1.7$, Decision of the Ministers' Deputies, Complementary procedure between the Committee of Ministers and the Parliamentary Assembly in response to a serious violation by a member State of its statutory obligations, 2020. február 5.

Parliamentary Assembly Resolution 1990 (2014), Reconsideration on substantive grounds of the previously ratified credentials of the Russian delegation, 2014. április 10.

COM/2014/0158 final, A jogállamiság megerôsítésére irányuló új uniós keret.

COM(2020) 580 final, Európai Bizottság, 2020 Rule of Law Report. 